\title{
Tracking the Elusive Undergraduate Non-user: Triangulating a Senior Survey, Library Instruction Data, and LibOUAL $+{ }^{\circledR}$ Results
}

\author{
Laurel Littrell \\ Kansas State University, USA
}

\begin{abstract}
Kansas State University collects survey data annually through a locally developed senior survey that includes questions about library use and satisfaction. The libraries use LibQUAL $+{ }^{\circledR}$ every three to four years, and the library instruction program collects data on what courses and programs use library instruction and how many students attend instructional sessions. What correlation might exist among these three data sets? Is there consistency between usage and satisfaction rates that can be linked with library instruction? From studying and comparing these results, there appears to be correlation in most instances. Further study of usage and impact of additional resources, such as customized online course guides, could provide additional insight, especially for areas with less formal library instruction but that still report a greater usage and satisfaction of the university libraries than areas with more library instruction. Examining the three sources of data broken down by college or discipline can also identify gaps in library contact and usage. These areas can be targeted for marketing and promotion of library services and resources.
\end{abstract}

\section{Purpose}

Generally, obtaining library use and satisfaction information from library users is not particularly difficult. Finding information about non-users of the library is quite another matter.

Kansas State University is an R-1 university with nine colleges: Agriculture; Architecture, Planning \& Design; Arts \& Sciences; Business Administration; Education; Engineering; Human Ecology; K-State Polytechnic Campus; and Veterinary Medicine. In addition to these are Global Campus, offering online degree programs in the various colleges, K-State Olathe offering courses and programs through the other colleges in the Kansas City area, and the Graduate School.

At Kansas State University Libraries, there are three sources of information that can provide insights about student usage of library services and resources at the college level.

- The locally developed Senior Survey asks questions about student use and satisfaction with many components of university life, including library services, resources, and facilities. Beginning in 2013, these results are available by college, for those colleges offering undergraduate degrees.

- The LibQUAL survey asks questions about frequency of use of resources on library premises or through a library webpage. These results also can be determined by college with careful mapping of the LibQUAL standard disciplines with those of the university.

- Library instruction data is tracked through LibAnalytics and includes the course code (tracked to a specific college) as well as course number (designating the level of course) and the number of students attending.

\section{Design and methodology}

By comparing these three sets of results, could one potentially track areas of the university that may be underserved by the libraries and target these areas for focused outreach and further study, if there is consistency in the data? Will the information be detailed sufficiently by discipline to provide useful insight? 


\section{K-State Senior Survey}

As is typical for most universities, Kansas State University offers an "exit survey" to graduating seniors. ${ }^{1}$ These efforts began in earnest in 1999 and have taken various forms over the years. In 2006, the survey expanded to query students about their broader experiences on campus, including interactions with fellow students, faculty, and various university services and components including library resources, staff, and services. These responses were on a five-point Likert-type scale (from very satisfied to very dissatisfied) and also included a "did not use" response. These results were aggregated to the entire university.

In 2009, the questions regarding university services and resources were changed from the Likert-type scale to asking the students to select one of the following options:

- Used and was satisfied

- Used and was dissatisfied

- Knew about but did not use

- Did not know about

Institutional memory has been lost as to the rationale for changing the responses accordingly, but the differences between "knew about and did not use" and "did not know about" seemed intriguing and useful. From this year on, the libraries tracked the senior survey data, pulling out the library-related questions and studying the responses longitudinally over the last ten years.

There are four questions on the senior survey that are library-related:

- Access to electronic library resources (databases, electronic journals, and books)

- Library staff (assistance in research, effectively finding information, learning how to use the libraries)

- Library holdings (quality and quantity)

- Library facilities (atmosphere, available seating, hours)

Other similar questions that students were asked related to residence hall facilities, various offices on campus-including the registrar, food services, concert and lecture series-and so on. There is interest in the libraries about the need to update the questions, with concern that students may not understand the terminology "library holdings" and the difference between that and "access to electronic library resources."

In 2013, Senior Survey results were made available to the campus community by the colleges that offer undergraduate degrees: Agriculture, Arts \& Sciences, Business Administration, Education, Engineering, and Human Ecology. Other colleges in the university, including Veterinary Medicine and Architecture, Planning \& Design, only offer graduate degrees. The colleges designated as Global Campus and K-State Olathe offer degrees through the other colleges. Another campus, K-State Polytechnic, has a separate library system and assessment methods and is also not included in this study. For these six undergraduate colleges, the K-State Office of Assessment employs PowerBI, a Microsoft Office 365 product, as a data visualization tool to provide access to survey results in a wide variety of demographic configurations, including by college. ${ }^{2}$

The two similar questions explored in this study, regarding the use of online library resources and the library facilities, can be seen longitudinally as below. 
Figure 1: Senior Survey ten-year results for access to electronic library resources. In 2017, library budget cuts resulted in a subscriptions cut, correlating with increasing dissatisfaction rates.

- Access to electronic library resources (databases, electronic journals and books) \%

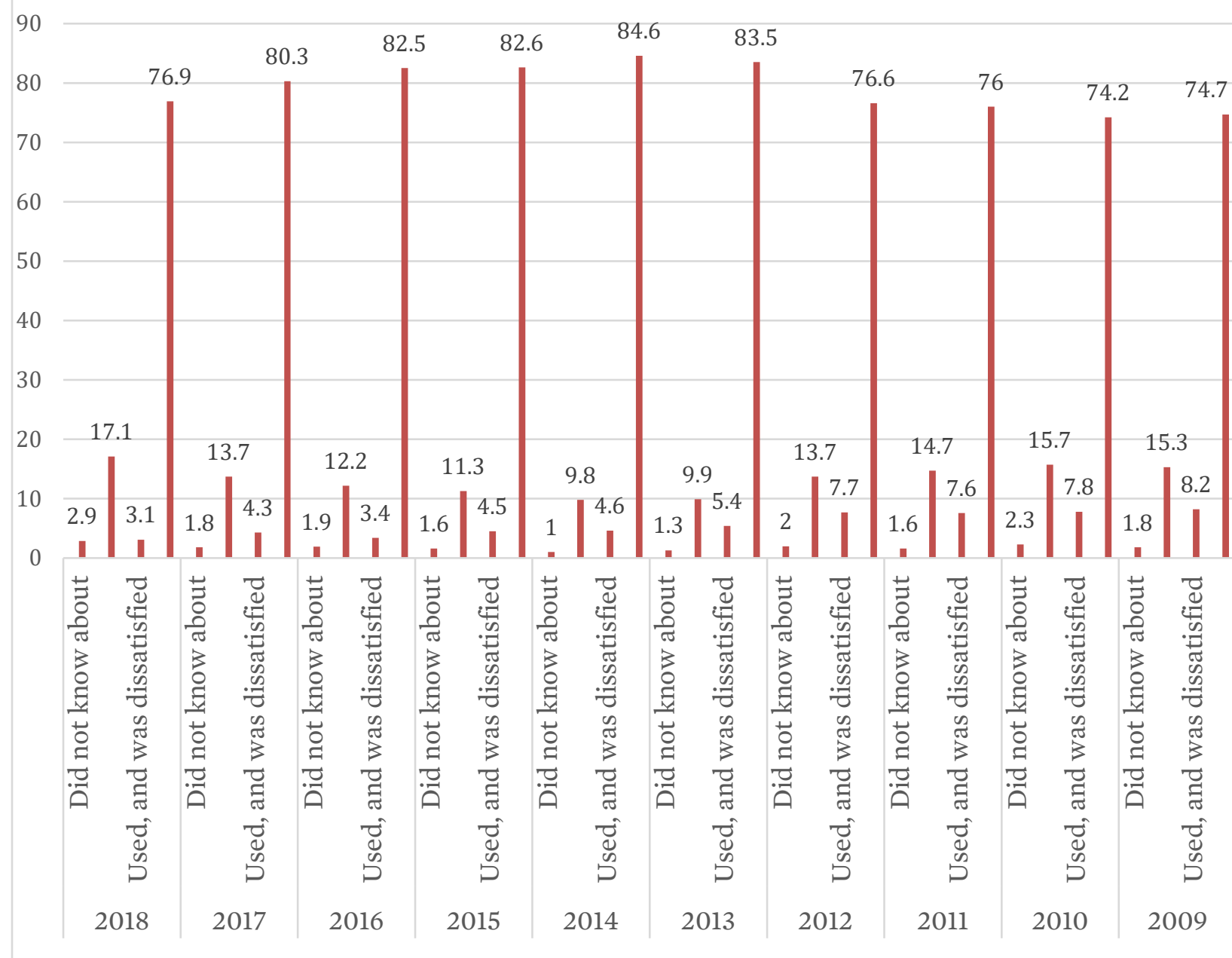


Figure 2: Senior Survey ten-year results for Library Facilities (atmosphere, available seating, hours). In 2016-2017, library hours were cut because of budget cuts, correlating with an increase in rates of dissatisfaction.

- Library facilities (atmosphere, available seating, hours) \%

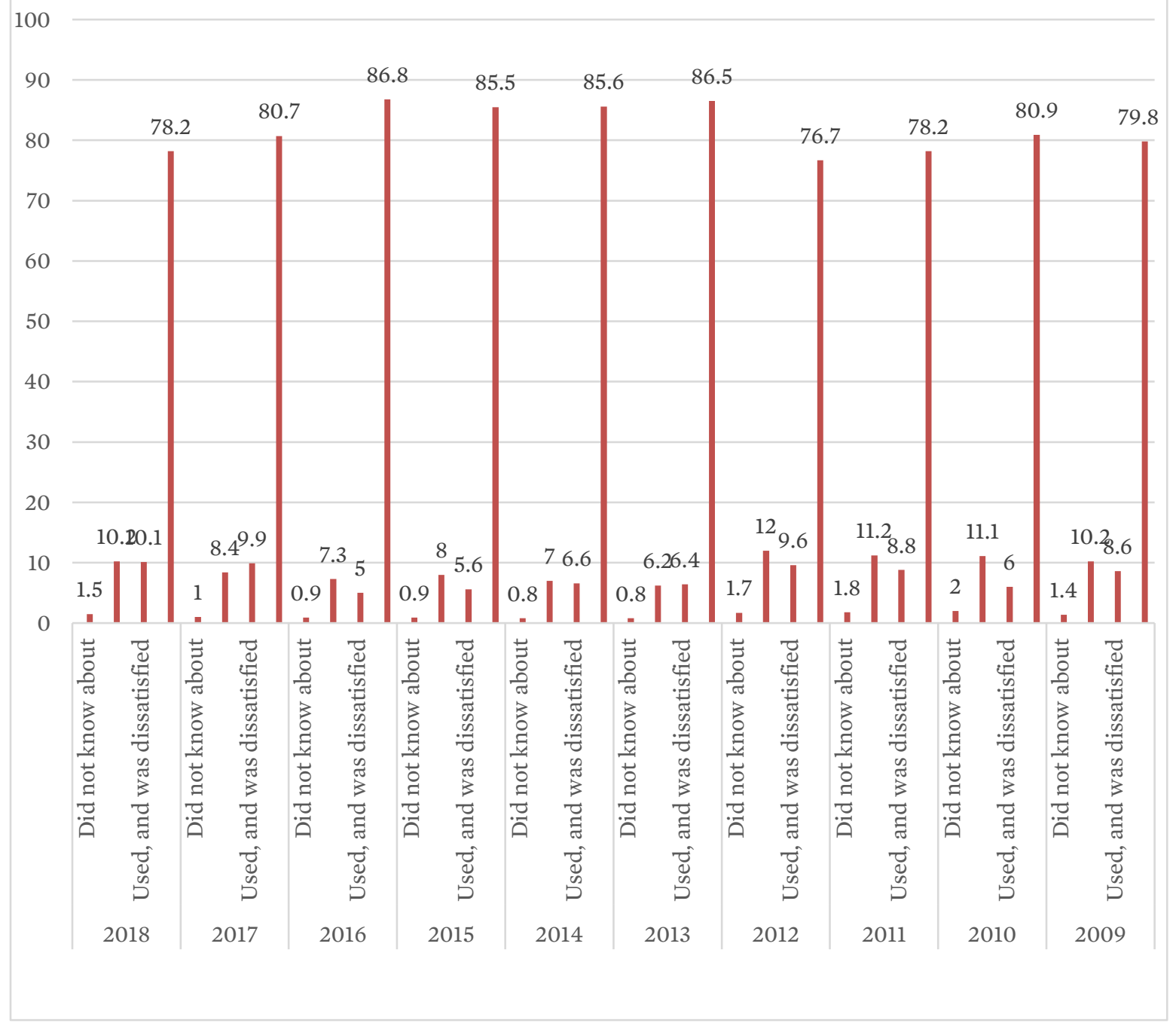

\section{LibQUAL}

Another tool used every three to four years by K-State is the LibQUAL survey. ${ }^{3}$ LibQUAL was used in 2007, 2011, 2014, and 2018. Results are compared longitudinally, both by user groups and by disciplines, and have yielded satisfactory results especially when the qualitative information provided (comments) is carefully considered and analyzed. LibQUAL's capability of determining areas of priority for user groups and disciplines, as well as respondents' self-reporting library usage, are particularly valuable for this study. For the 2018 iteration of LibQUAL, the standard disciplines used by LibQUAL were mapped more closely to correspond to the colleges of the university, particularly smaller colleges such as Human Ecology, Veterinary Medicine, Agriculture, Education, etc. This was more difficult for the College of Arts and Sciences, the largest college at K-State, but the broad discipline areas (humanities, social sciences, etc.) offered opportunities for more granular data that will be useful for other projects. 
By studying the results of the LibQUAL questions that inquire about usage of the library, including frequency of using resources "on premises" and using resources through library webpages, one can compare similar usage data reported in the same college from both the Senior Survey and from LibQUAL. Pleasantly, but not surprisingly, consistency existed between these two data sources. As part of the LibQUAL service, one must indicate the number of students in each discipline/college so one can determine the representativeness of survey respondents. This groundwork also was useful in studying the Senior Survey data and subsequent representativeness when comparing the 2018 LibQUAL data with the 2018 Senior Survey data.

Figure 3: LibQUAL Library Use Chart for Undergraduates, 2018

Library Use Chart

Kansas State University Libraries (LQ 2018)

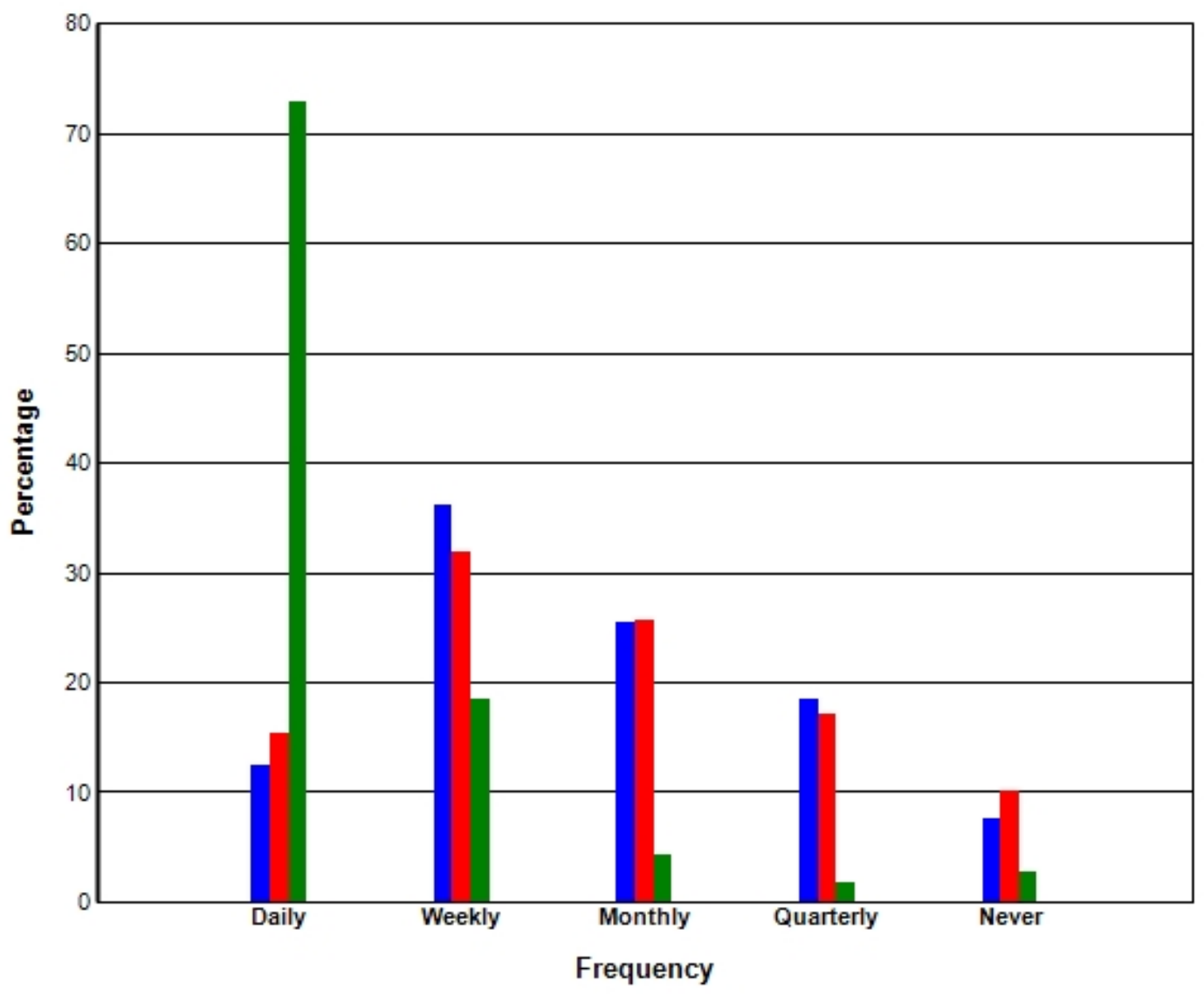

How often do you use

resources on library

premises?

How often do you

access library resources through a library Web page?

How often do you use

Yahoo(TM), Google(TM), or

non-library

gateways for information? 
Figure 4: LibQUAL $+^{\circledR}$ Library Use Chart for Undergraduates, 2014

Library Use Chart

Kansas State University Libraries (LQ 2014)

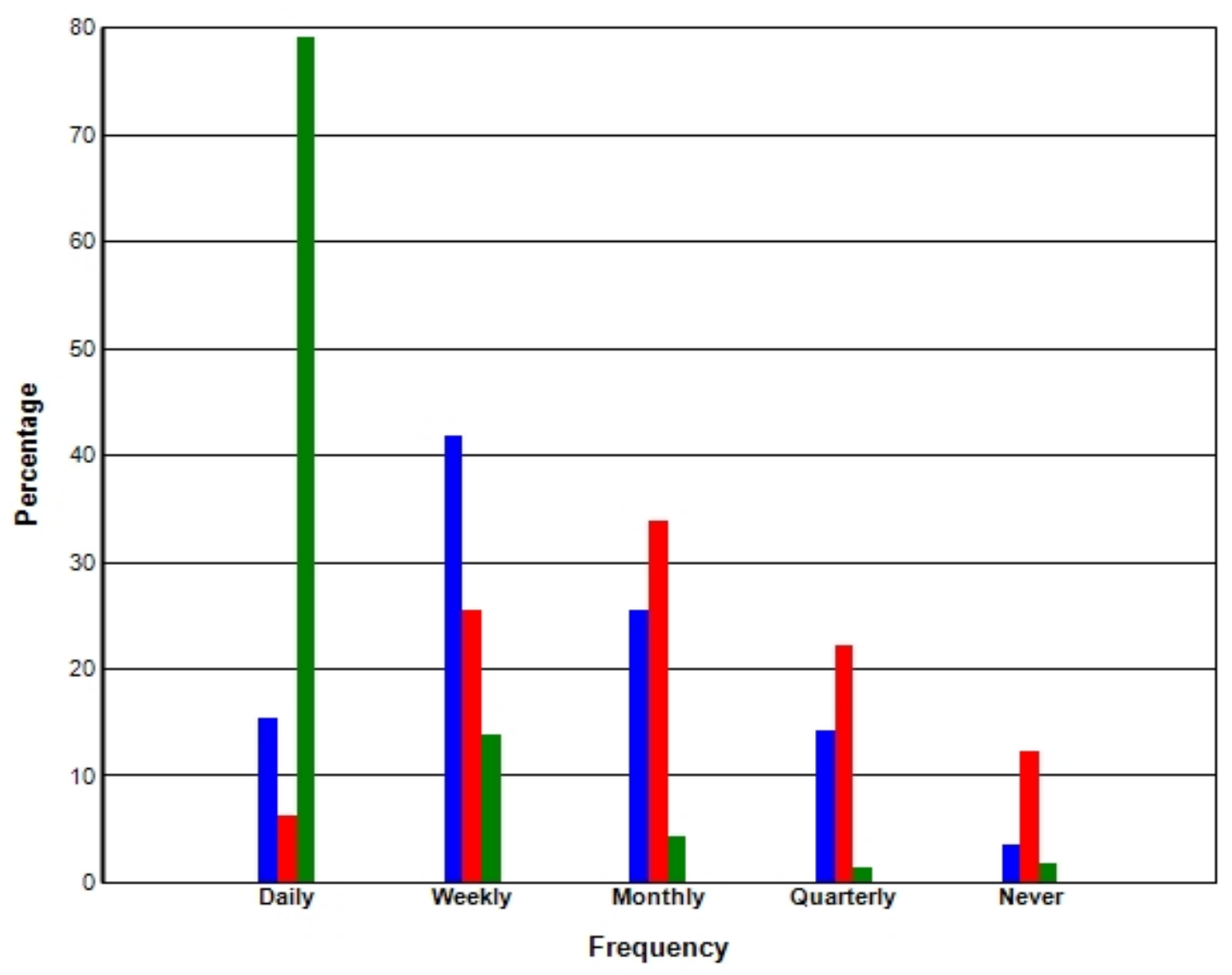

How often do you use

resources on library

premises?

How often do you

access library resources

through a library Web page?

How often do you use

Yahoo(TM), Google(TM), or

non-library

gateways for information?

\section{Library Instruction Data}

Information about library instruction has been tracked through LibAnalytics beginning in fall 2013. ${ }^{4} \mathrm{By}$ determining what college offered each particular course librarians worked with, the number of classes and students attending these classes for the 2017-2018 year could be gathered, corresponding with the latest LibQUAL and Senior Survey data. Would there be any link to the number of students reached through instruction with the number of students reporting library usage through the two surveys? Would any useful correlation exist? By comparing the number of students in each program with the number of students 
experiencing library instruction, a possible percentage of students from each college affected could be determined. However, there are many problems with this method.

- All students are required to take courses in the College of Arts \& Sciences for general education requirements. In an attempt to offset this, only upper level courses were analyzed with the idea that students taking an upper level undergraduate course are more likely to be seeking a degree from that college; this, however, is certainly not completely accurate.

- Students frequently change majors and take courses in other colleges. This analysis cannot compensate for those.

- Interdisciplinary studies, minors, and certificates that span more than one college are becoming more frequent.

- Some students undoubtedly are counted twice (or more), inflating the percentages of participants in instruction.

- Sample sizes, when broken down by college, begin to get very small.

- Librarians create online research guides for disciplinary areas and courses. The impact of these guides and students working one-on-one with librarians outside of classroom library instruction cannot be factored into this study.

- Existing branch libraries mainly affect a few graduate programs of the university (Veterinary Medicine, Architecture), with the lone exception of the Math/Physics library. All other undergraduate programs rely almost exclusively on the main campus library.

After studying these problems with correlating this data, one might inquire as to the usefulness of this comparison, but a couple of factors do support the study of this data.

- Consistency exists between the three data points; however, even within all three, sample sizes become small enough to bring some concern.

- None of these results are surprising to any of the librarians working with these programs.

\section{Triangulating the Available Data}

Both surveys used-the Senior Survey and LibQUAL-ask similar questions about library usage and offer this information broken down by college. The 2018 LibQUAL disciplines were mapped much more carefully than previously to correspond with the colleges (with the exception of Arts \& Sciences). The wording of both sets of similar questions was somewhat different.

Terminology of two Senior Survey questions:

- Access to electronic library resources (databases, electronic journals and books)

- Library facilities (atmosphere, available seating, hours)

Requested responses for both questions:

- Used and was satisfied

- Used and was dissatisfied

- Knew about but did not use

- Did not know about 
Terminology of two LibQUAL questions:

- How often do you use resources on library premises?

- How often do you access library resources through a library Web page?

Requested responses for both questions:

- Daily

- Weekly

- Monthly

- Quarterly

- Never

For this study, the Senior Survey responses to analyze were selected as "Knew about but did not use," "Did not know about," and "Used and was dissatisfied." For LibQUAL, responses for "Never" were selected. Results for these by college were compared, along with representativeness for both surveys and mapped against the instruction data.

\section{Representativeness}

Library instruction was offered to 192 upper level undergraduate courses in $2017-2018$, reaching $36.5 \%$ of upper level undergraduate students. Among the six undergraduate colleges included in this study, percentages ranged from $64.1 \%$ of students in the College of Education to $9.0 \%$ in the College of Engineering, with $13.8 \%$ in the College of Agriculture. The remaining three colleges (Arts \& Sciences, Business, and Human Ecology) all ranged from 30 to $39 \%$.

LibQUAL representativeness was fairly evenly spread across the colleges, with 4-6\% of undergraduates responding from each college. Senior survey responses ranged from $7-10 \%$ across the various colleges. Although response rates were lower than one would hope, the evenness of the rates across the colleges is useful to consider although sample sizes are small.

\section{Findings}

Notable consistency exists between the LibQUAL data and the Senior Survey regarding library use, awareness, and satisfaction in various disciplines. The level of activity in instruction, for the most part, mirrors these results as well and can assist librarians in pinpointing areas of the university that are underserved by the libraries, particularly for areas that showed greater dissatisfaction or were less aware of library resources available.

Three of the six colleges stood out with particular responses. Positively, the College of Education saw a high of $64.1 \%$ of upper level students experiencing library instruction. These students also had the highest LibQUAL response with $6.4 \%$ of undergraduates in the college responding. Correspondingly, these students reported the highest rates of onsite library usage and the highest rates of satisfaction with resources and library facilities. Possible contributions to this could possibly be that this is the smallest college, is very closeknit residing in one building on campus, the education building happens to be right next to the large main university library, and the education librarian is a long-term well-experienced librarian with a stellar instructional and faculty partnership record. What is particularly notable is that, out of all the colleges, the College of Education is the only one that reported on the Senior Survey that no students did not know about the availability of library resources and facilities (although a few chose not to use them). 
Figure 5: Senior Survey reporting for library resources and facilities, College of Education, 2018 College of Education Senior Survey, 2018, \%

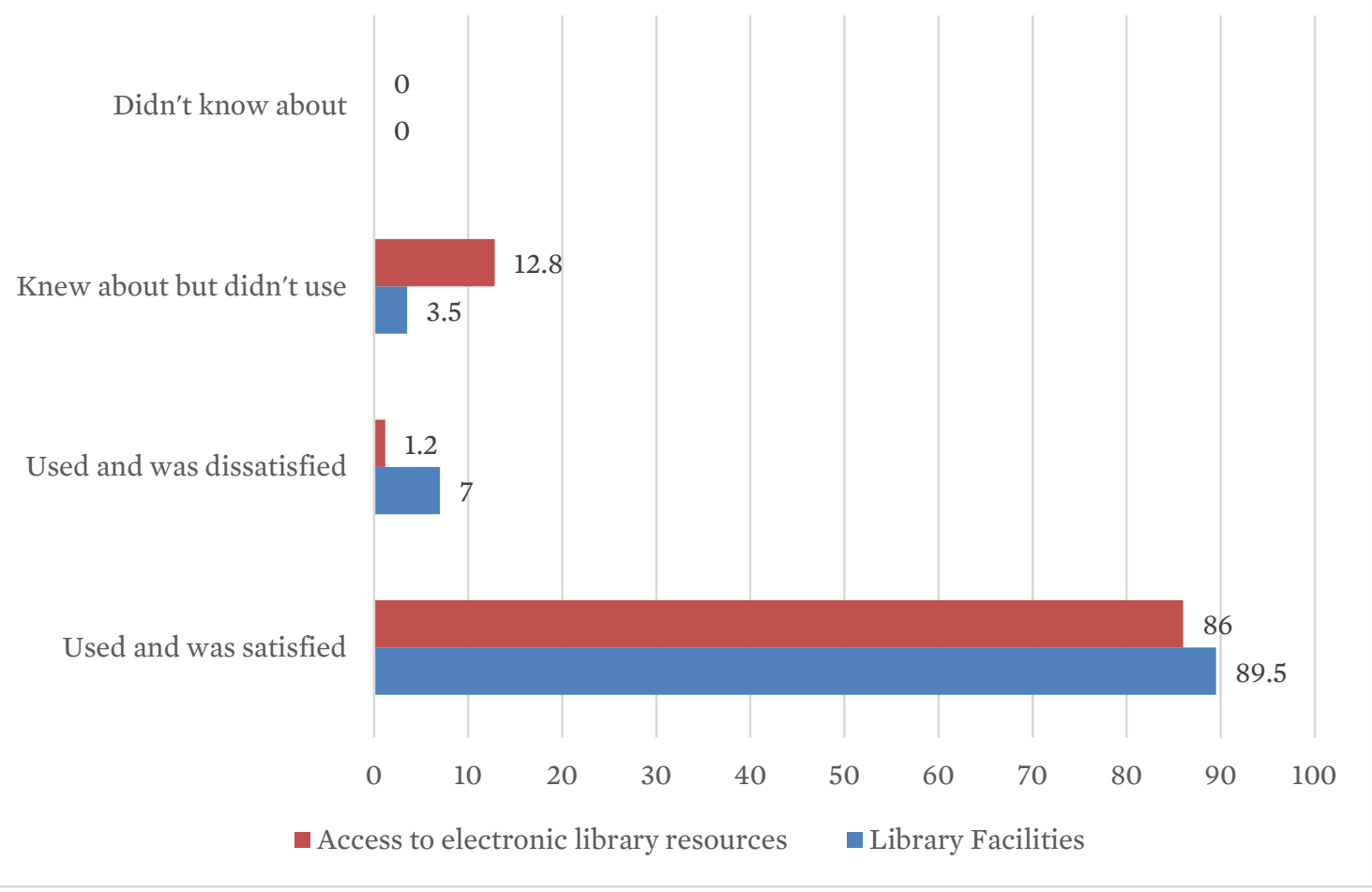


Figure 6: LibQUAL usage report for College of Education, 2018

Library Use Chart

Kansas State University Libraries (LQ 2018)

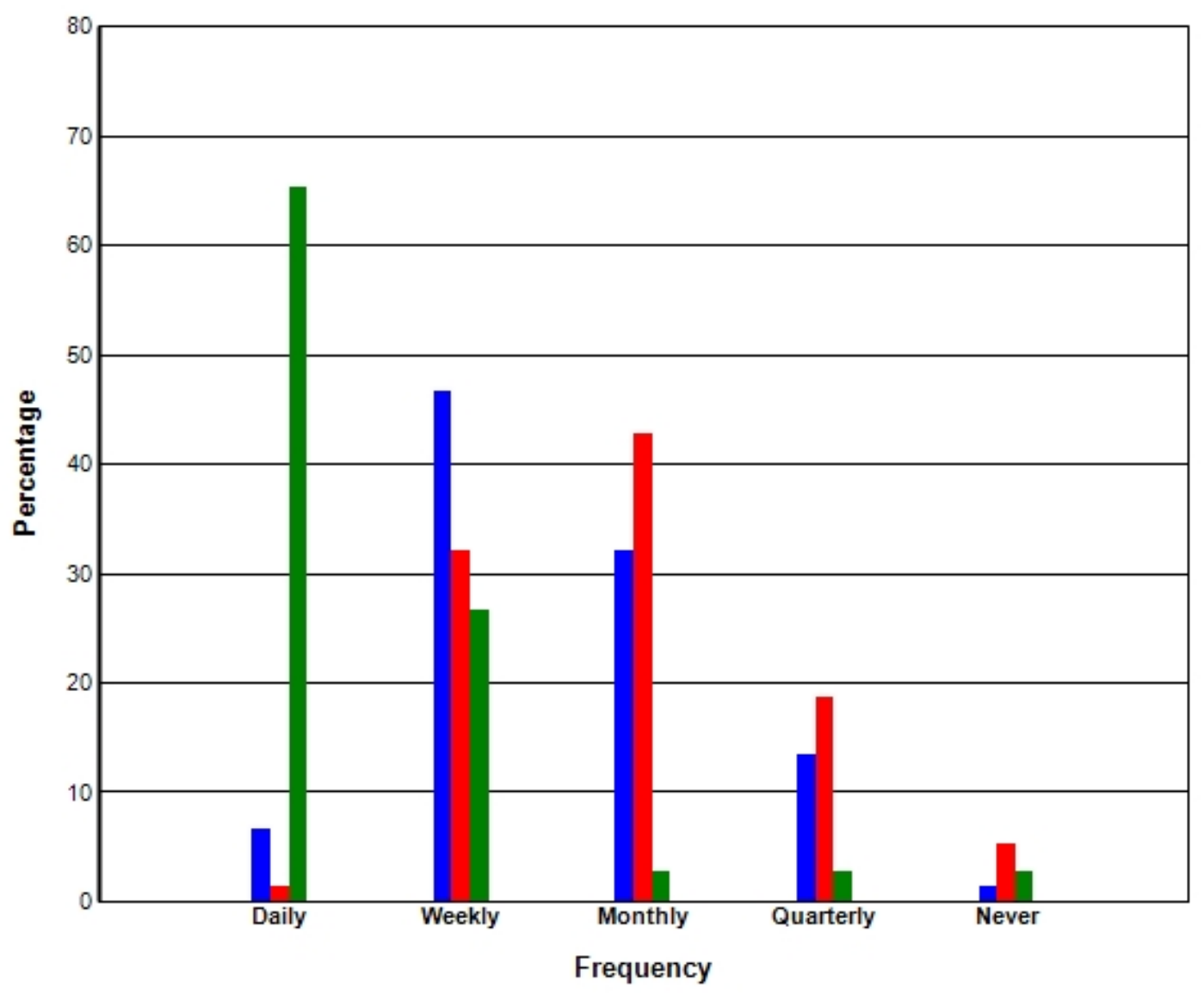

How often do you use

resources on library

premises?

How often do you

access library resources

through a library Web page?

How often do you use

Yahoo(TM), Google(TM), or

non-library

gateways for information?

The College of Engineering had the lowest rate of upper level student instruction with $9.0 \%$ students reached, but these students did not report a particularly low rate of usage or expressed any particular dissatisfaction with library facilities or resources. Some unusual factors about this college include the decision by the college in May 2015 to close the branch engineering library. The engineering librarian has made a significant effort above and beyond most disciplines to provide comprehensive online research guides for various engineering topics, although determining the impact of these guides is far beyond the 
scope of this paper. A longitudinal study of the impact of the closure of this library would provide more useful information.

The third college that appears more affected by library instruction is the College of Agriculture. The percentage of students participating in library instruction for this college is the next smallest to Engineering (13.8\% for agriculture). In the Senior Survey, this college also reported the smallest use of online resources and library facilities, although this was not borne out in LibQUAL.

The College of Agriculture at Kansas State University is large and distributed. Although the College of Arts \& Sciences is larger in terms of student and faculty headcounts, the College of Agriculture is massive in terms of building footprint, research centers, and land acreage with extensive farming and ranching operations, either on the edges of the main campus or varying miles away. Students, staff, and faculty are scattered across a large geographic region. The agricultural studies librarians are well aware of the issues and have been working diligently to promote library collections and services. The use of online resources and services has improved communications tremendously, but complicating matters are the many independently operated libraries/reading rooms that have sprung up in these locations that are outside of the main library system. Students are confused about the organizational place of these reading rooms and often make comments about them on surveys such as LibQUAL, including asking for renovations to the spaces or additional resources.

Figure 7: Senior Survey reporting for library resources and facilities, College of Agriculture, 2018

College of Agriculture Senior Survey, 2018, \%

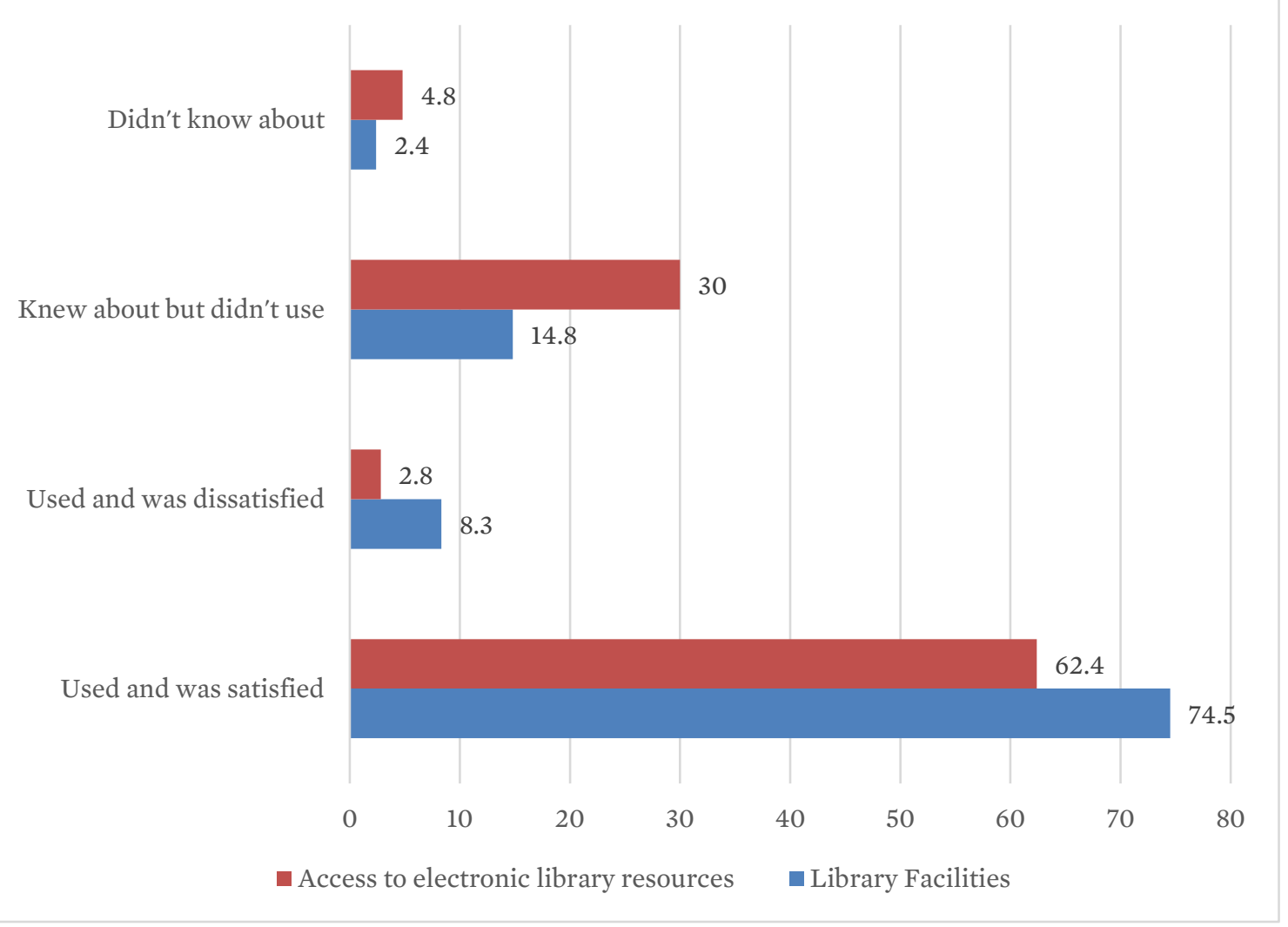


Figure 8: LibQUAL usage report for College of Agriculture, 2018

\author{
Library Use Chart
}

Kansas State University Libraries (LQ 2018)

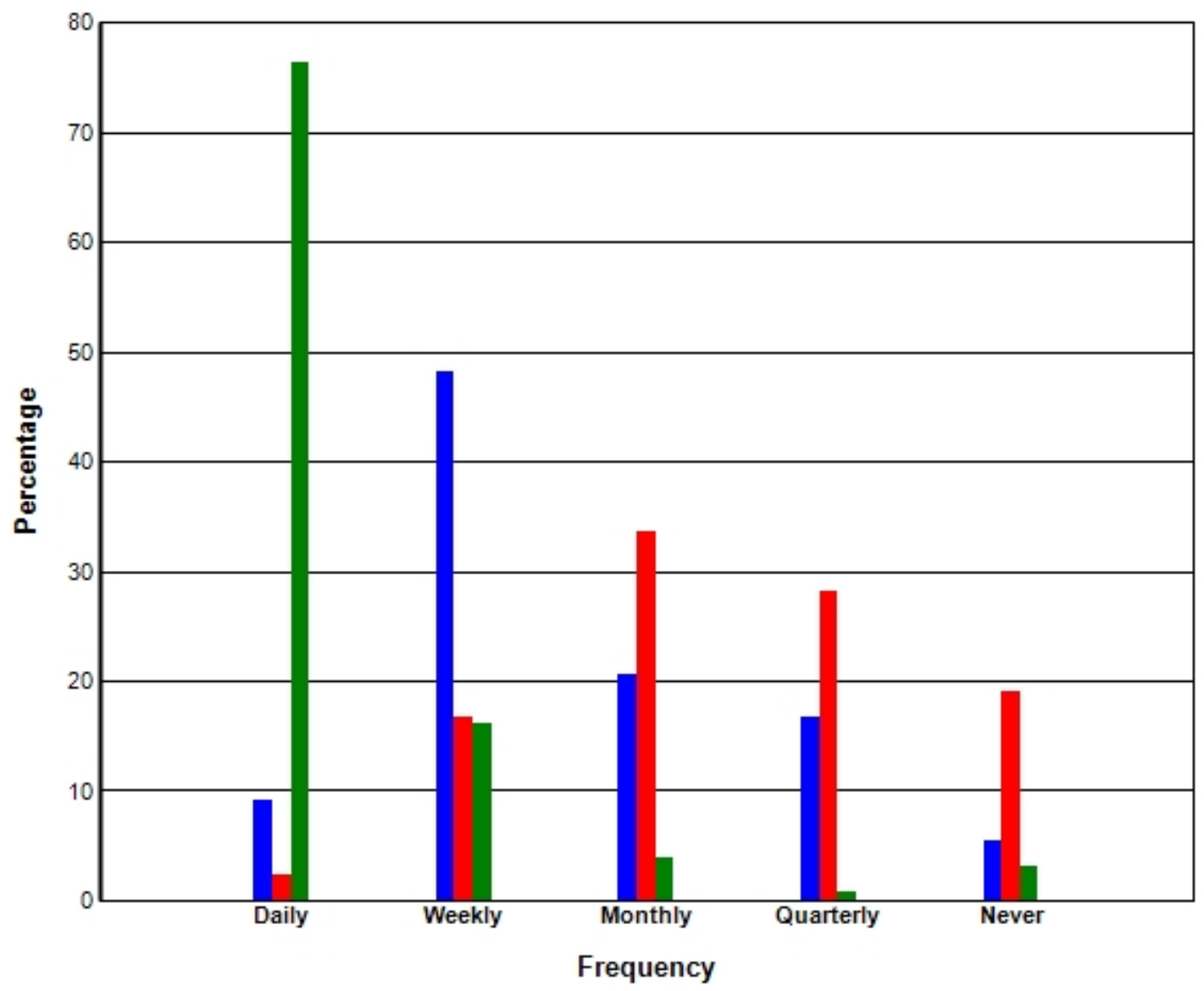

How often do you use

resources on librany

premises?

How often do you

access library resources

through a library Web page?

How often do you use

Yahoo(TM), Google(TM), or

non-library

gateways for information?

Another interesting component to study would be the effect of proximity to physical libraries, particularly for undergraduates who value the study spaces and available technology. Does this proximity positively affect the College of Education's use of library spaces, and more to the point, does it affect even the use of online library resources? Drilling down into the program level in the larger colleges would be useful as well. One or two agricultural departments are close to the main library; would these report greater library usage than those much further away, even for online resources? What link, if any, exists? 


\section{Practical implications and value}

As is typical with many studies of this nature, more additional questions are raised than are answered and some of these will be worth pursuing. To further complicate matters, the main campus library at K-State, Hale Library, was extensively damaged by toxic smoke and water during a roof fire in May 2018. With heavy reliance on a large central library with only three small branch libraries available, disciplines that rely on print/historical resources are particularly hard-hit, as are students who depended on the library to provide study space and necessary technology for their successful academic endeavors. The effect of this disaster will overshadow any assessment efforts in the future, but will provide unique opportunities to demonstrate library value in ways that could not be done through any other means. One would certainly not intentionally completely close a large central library unexpectedly for two years as an experiment, including making nearly all the physical collections unavailable. The advantage is that the opportunity does exist to study the ramifications of this closure, but, of course, one must consider the enormous disadvantage of the tremendous negative impact to many students' individual academic efforts. At any rate, there will be lessons to learn and studies to make about providing library resources, collections, and spaces when the means to deliver these has been abruptly removed for an extended period of time.

Aside from the fire coming on the heels of this study, there are aspects to consider for other institutions. For areas that report more "did not know about" or "did not use" responses, it may be possible to probe more deeply with students and instructors about why-what resources are they using instead? Are there locally available resources within the program? Are they using tools that are provided by the libraries but are unaware who provides them? How can we improve our communications and outreach with these areas?

The opportunity to identify areas of the university with more non-users is a valuable tool and could provide a model for other institutions that utilize similar surveys for students.

Figure 9: Percent of students taught in upper level undergraduate courses for each college

\section{students taught, \% of students in the college}

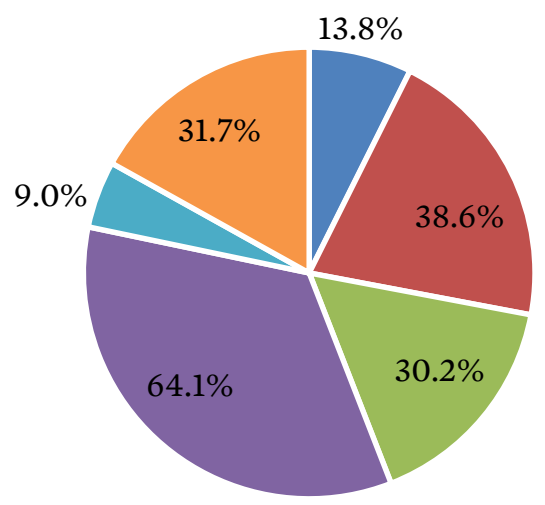

$$
\begin{aligned}
& \text { - Agriculture } \quad \text { Arts \& Sciences } \backsim \text { Business } \\
& \text { - Education } \quad \text { Engineering } \quad \text { Human Ecology }
\end{aligned}
$$


Figure 10: Percent of students reporting lack of use or dissatisfaction with library facilities, compared with percent taught for each college, 2018

\section{lack of use or dissatisfaction with library facilities, with \% taught}

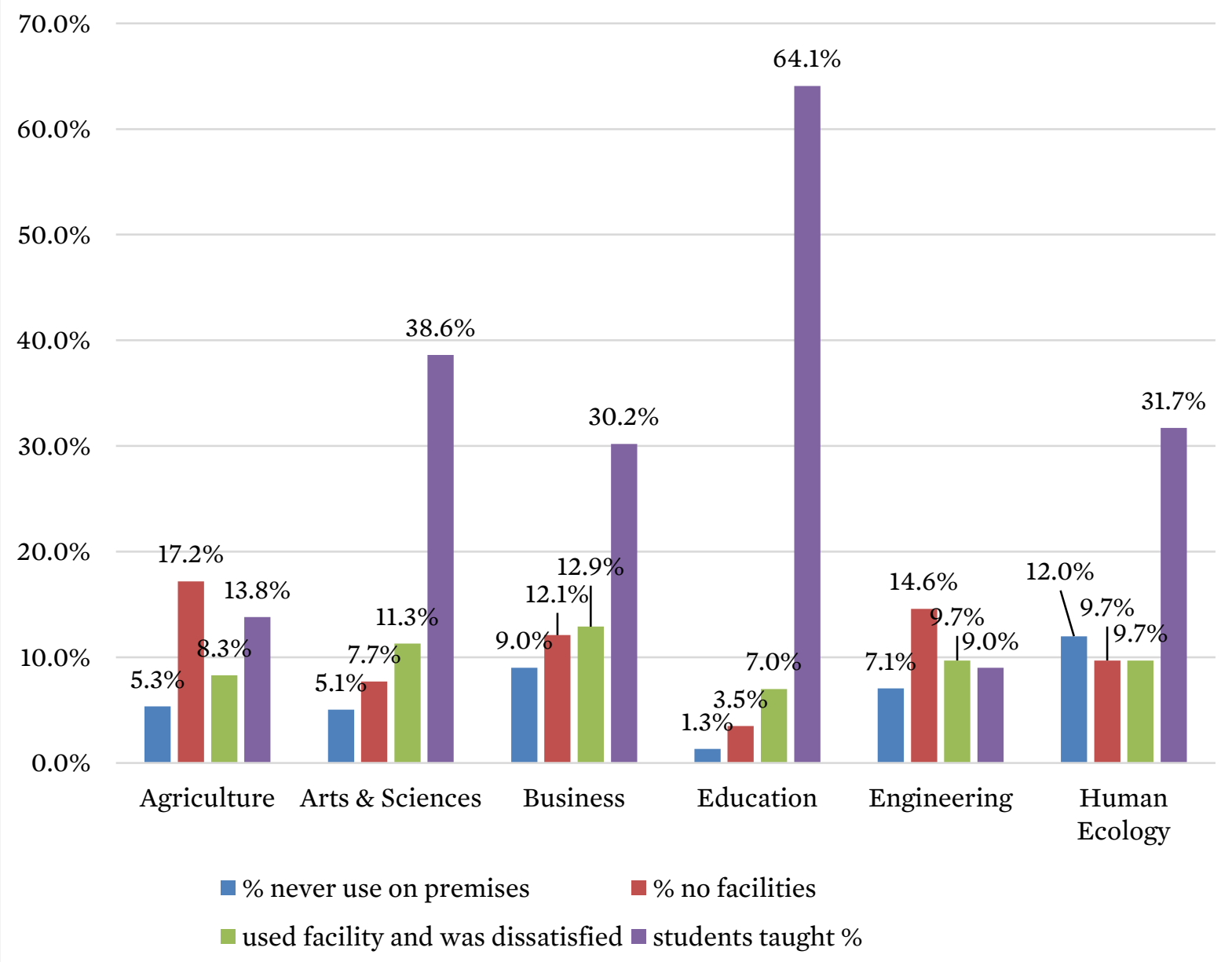


Figure 11: Percent of students reporting lack of use or dissatisfaction with online library resources, compared with percent taught in each college, 2018

\section{lack of use or dissatisfaction with online resources, and \% taught}

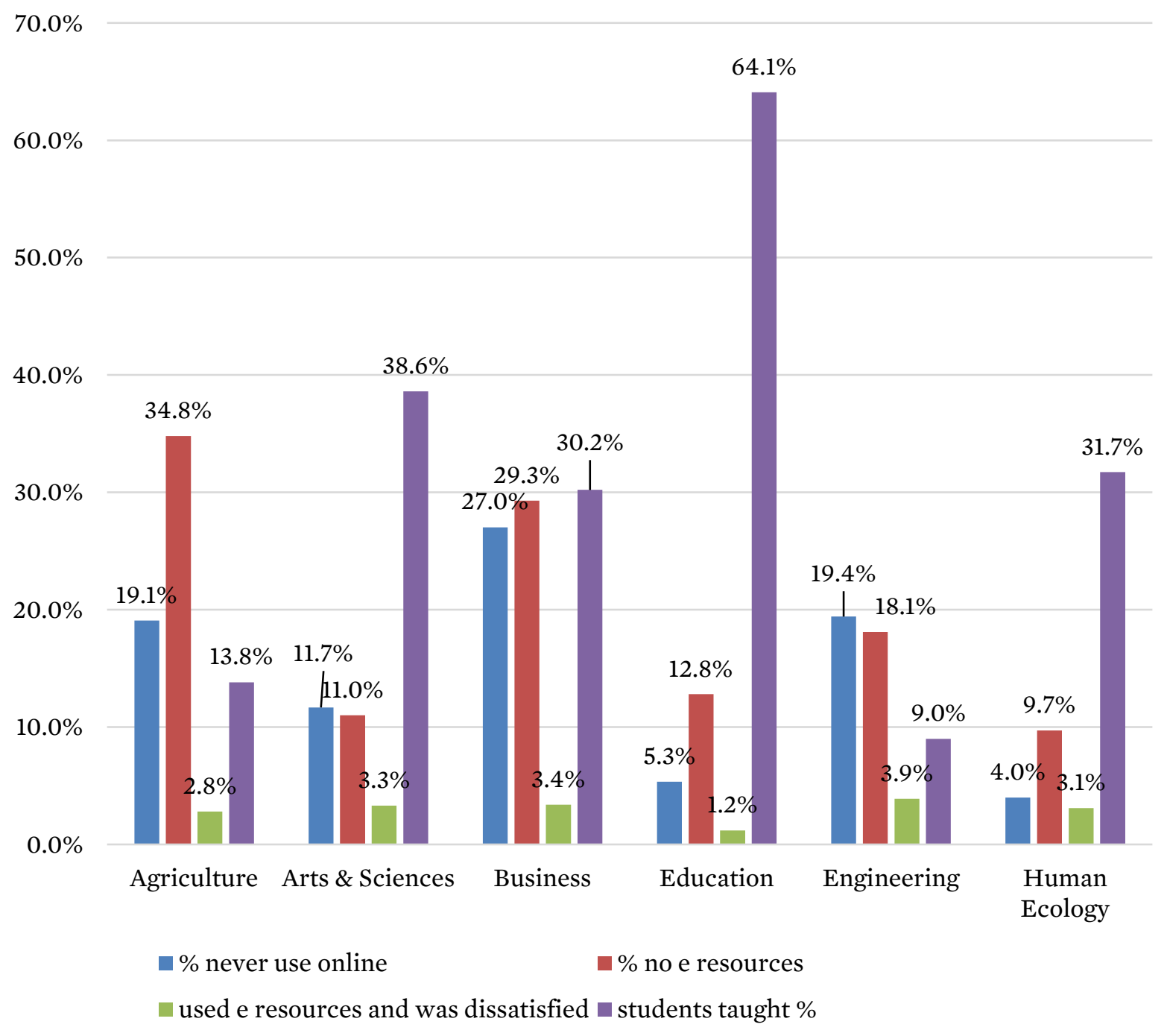

-Copyright 2019 Laurel Littrell

\section{Endnotes}

1. "Senior Survey," Kansas State University Office of Assessment, last modified June 27, 2018, https://www.k-state.edu/assessment/surveys/seniorsurvey/.

2. PowerBI, accessed October 1, 2018, https://powerbi.microsoft.com/.

3. LibQUAL ${ }^{\circledR}$, accessed October 1, 2018, https://www.libqual.org.

4. LibAnalytics, from SpringShare, can be used to track reference transactions, instructional sessions, and other information. It has largely been replaced by LibInsight from the same company.

https://blog/springshare/com/category/libanalytics/. 